\title{
Social Network Analysis and Learning Communities in Higher Education Online Learning: A Systematic Literature Review
}

\author{
Shazia K. Jan, Panos Vlachopoulos, and Mitch Parsell \\ Macquarie University, Australia
}

\begin{abstract}
This paper presents the results of a systematic literature review which sets out to explore the use of social network analysis (SNA) for investigating learning communities specifically, communities of practice $(\mathrm{CoP})$ and community of inquiry $(\mathrm{CoI})$ in higher education online learning (HEOL). The impetus for such a review originated from the reliance on extensive and time-consuming qualitative analysis typically required in research involving the CoP and CoI frameworks. The review consolidates and synthesizes existing research in HEOL in search of a methodological framework for structurally evaluating a CoP and/or CoI using SNA. We identified a handful of studies that integrate SNA measures and key structural components of the $\mathrm{CoP}$ and $\mathrm{CoI}$ frameworks and examined: SNA measures and corresponding theoretical components used; other analytical techniques used; limitations and; suggestions for further research. The selected studies reported disparate findings in terms of the relationship between SNA measures and the CoP and/or CoI components. The review also highlighted the need to complement SNA with a qualitative analytical technique. Therefore, whether SNA has the potential to be used as a stand-alone technique for structurally identifying communities remains to be seen. We also find a lack of consideration to attributional and performance variables in existing studies. In conclusion, we propose further research and the development of a fully integrated methodological framework which uses SNA to structurally evaluate a CoP and CoI.
\end{abstract}

Keywords: social network analysis, online learning, communities, systematic review

Jan, S.K., Vlachopoulos, P., \& Parsell, M. (2019). Social network analysis and learning communities in higher education online learning: A systematic literature review. Online Learning, 23(1), 249-265. doi:10.24059/olj.v23i1.1398

\section{Social Network Analysis and Learning Communities in Higher Education Online Learning: A Systematic Literature Review}

The adoption of online learning by a progressive number of institutions (Allen, Seaman, Poulin, \& Straut, 2016) has necessitated and accelerated research into pedagogical practices in the online space. Note that the we use the term "online learning" and "e-learning" to refer to purely online and blended courses and use the terms inter-changeably where necessary. A large amount of research on online learning draws from Vygotsky's (1978) social constructivist theories of learning (Smith, 
Hayes, \& Shea, 2017), rooted in Dewey's (1938) concept of student-driven learning through engagement, active learning and collaboration, the pedagogical foundations of learning communities. The importance of learning within communities rests on decades of research dating back to the $1920 \mathrm{~s}$ (Smith, 2001). Following a relatively quiet period, the community learning idea re-emerged in the mid-1990s when several studies were published associating learning within a community with positive outcomes for university students (Zhao \& Kuh, 2004). In 1991, drawing from Dewey and Vygotsky's social constructivist ideas, Lave and Wenger (1991) proposed the situated learning theory which describes learning as a social process situated within a community of practice (CoP). As online learning gained momentum in the early 1990s, learning in communities became the holy grail of online learning as evidenced by the view that "without the support and participation of a learning community, there is no online course" (Paloff \& Pratt, 1999, p.29). Onwards, the introduction of social learning technologies and collaborative learning further propelled the community learning movement. In 2000, also rooted in social constructivist and situated learning perspectives, Garrison, Anderson and Archer (2000) developed the community of inquiry (CoI) framework as a model for online teaching, learning, and research.

Both the $\mathrm{CoP}$ and $\mathrm{CoI}$ frameworks address learning within the structure of a community grounded in a network of relationships and have been commonly applied to research on networked learning (Conole, 2011). However, a majority of the research involving the frameworks is qualitative and time-consuming, as it relies on extensive content analysis of online communication transcripts (Garrison, 2017; Wenger, McDermott, \& Snyder, 2002). The development of the CoP framework was rooted in the context of professional learning whereby novices in a community learn from and gradually evolve into experts whereas the $\mathrm{CoI}$ framework was specifically developed as a guide for online pedagogy and research. Interactions and the nature of these interactions within networks of learners are the basic underlying concepts in both a $\mathrm{CoP}$ and CoI. However, since the communities are conceptually distinct, the structure of the networks underlying the communities is expected to be unique. The question then arises, can structural differences be used to evaluate and identify a $\mathrm{CoP}$ and CoI?

At this point, a clarification of the distinction between a network and a community and of their relationship to one another is warranted. A network is simply defined as "a set of connections among people... used for solving problems, sharing knowledge, and making more connections" (Wenger, Trayner, \& De Laat, 2011, p.9). Alternatively, a community is "a group of individuals identifiable by who they are in terms of how they relate to each other, their common activities and ways of thinking, and their beliefs and values" (Biza, Jaworski, \& Hemmi, 2014, p.162). A network provides the social structure underpinning a community while a community provides the social mechanism through which knowledge is generated within a network. A community is a network however, a network is not necessarily a community (Wenger, 1998). Social network analysis (SNA), a quantitative analytical technique, has commonly been used to analyse and visualize networks.

SNA is an interdisciplinary technique for investigating relationships between entities or nodes in a network. SNA distinguishes itself from other analytical approaches as it allows for visual representation of data; emphasises relations between nodes as opposed to individual attributes (Freeman, 2006); examines activities of nodes influenced by the structure of the relational networks (Wasserman \& Faust, 1994); studies the flow of resources or information between nodes (Wasserman \& Faust, 1994); and can be applied at the individual (micro) and/or aggregate (macro) level (Borgatti, Everett, Martin, \& Johnson, 2013). The history of SNA dates to the 1930s (Moreno, 1953) however, it was not until 1954 that the term "social network analysis" was formalised into a theoretical 
perspective including concepts from graph theory, statistics, and probability. SNA has been used to study complex social interactions in various fields, for instance, healthcare (Chambers, Wilson, Thomson, \& Harden, 2012), communication (Haythornthwaite, 1996), education (Aviv, Erlich, Ravid, \& Geva, 2003), economics (Granovetter, 2005), political science (Ward, Stovel, \& Sacks, 2011), and engineering (Senghore, Campos-Nanez, Fomin, \& Wasek, 2014).

SNA is being increasingly applied to the field of higher education online learning (HEOL) primarily due to the availability of big data, that is, large amounts of data stored in institutional learning management systems (LMS) (Picciano, 2012). In the context of HEOL, nodes in the network represent students, lecturers, or tutors and the connections indicate online interactions within the LMS. SNA falls under the realm of social learning analytics, a category of learning analytics defined as the "measurement, collection, analysis and reporting of data about learners and their contexts, for purposes of understanding and optimizing learning and the environments in which it occurs" (LAK, 2011, para.6). Numerous studies have used SNA to investigate various aspects of e-learning (Cela, Sicilia, \& Sanchez 2015). Cela et al. (2015) identified a total 37 studies published between 1999 to 2012 using SNA in e-learning contexts. Topics examined included interactional analysis, effectiveness of specific technologies, identification of group structures, and the roles of students, lecturers, and tutors. However, the field of learning analytics is in its infancy (Avella, Kebritchi, Nunn, \& Kannai, 2016) as the potential and pedagogical value of techniques such as SNA has yet to be fully realized.

The intricate relationship between networks and communities, structural parallels between the two, and access to retrospective and real-time big data from LMSs, make SNA the ideal technique for structurally investigating a $\mathrm{CoP}$ and $\mathrm{CoI}$ in HEOL. This systematic review aims to find out if this has been done before and if so, how? The key objective of the review is to synthesize and evaluate literature that investigates a CoP and CoI using SNA and therefore establish the availability or lack of an integrated methodological framework for structural identification of learning communities. Specific research questions guiding the review are listed in the review protocol below. Prior to presenting the systematic review and our findings, in the following section we present an overview of the $\mathrm{CoP}$ and $\mathrm{CoI}$ frameworks with an emphasis on the structural components of each.

\section{Theoretical Frameworks}

\section{Communities of Practice}

Lave and Wenger (1991) introduced the theory of situated learning which postulates that learning takes place in a social context where knowledge is constructed collectively. They presented the seminal idea of legitimate peripheral participation, a process by which newcomers enter a group and eventually evolve into experts by learning and adopting practices of the group. This cyclical activity signifies learning as it leads to the development of individual and collective identities through the processes of participation and reification. Wenger (1998) discusses three aspects of practice that define a CoP: mutual engagement, joint enterprise, and shared repertoire. Mutual engagement refers to interactions between participants that lead to the construction of common meaning through negotiation. Joint enterprise refers to the process of mutual engagement and actions towards achieving a shared goal. Shared repertoire refers to the common resources and terminology used within the community. Wenger (1998) conceptualizes identity as a mode of belonging to a CoP via engagement, imagination, and alignment (p.173). Wenger, McDermott, and Snyder (2002) revise the three aspects of a CoP to domain, community, and practice where the domain is the common ground which defines the identity of the group, the community is the web of social relationships, and the practice is the 
shared repertoire of resources. In Wenger, White, and Smith (2009), the role of technologies in a CoP is brought into focus with the introduction of the idea of a digital habitat. The key to a sustainable thriving digital habitat is to find the right balance between three inherent polarities which drive communities to adopt technologies. These polarities include: rhythms (togetherness and separation), interactions (participation and reification), and identities (individual and group).

Even though the CoP framework has evolved over time, interactions between members of the community remain at the crux of the framework. To reiterate, reification requires participation (Wenger, 1991), negotiation of meaning comes from mutual engagement which leads to a sense of belonging (Wenger, 1998), a CoP is embedded in a network of social relationships (Wenger, McDermott, \& Snyder, 2002), and finally the rhythms of togetherness and separation, and participation and reification sustain a CoP (Wenger, White, \& Smith, 2009). Thus, even though a structural investigation alone of the underlying network of the community does not allow for a holistic evaluation of a $\mathrm{CoP}$, we believe it can provide critical insight into community dynamics.

\section{Communities of Inquiry}

The CoI framework was developed by Garrison, Anderson, and Archer (2000) as a guide for online learning practice and research and is used to inform methodologies and approaches to online learning design and delivery. It consists of three intersecting elements namely, social presence (SP), cognitive presence (CP), and teaching presence (TP). SP is defined as "the ability of participants in a community of inquiry to project themselves socially and emotionally as 'real' people..." (Garrison, Anderson, \& Archer, 2000, p.94). CP is "the extent to which learners are able to construct and confirm meaning through sustained reflection and discourse" (Garrison, Anderson, \& Archer, 2001, p.89). TP "manages the environment and focuses and facilitates learning experiences" (Garrison \& Kanuka, 2004, p.98) and is not specific to the tutor hence the use of the term teaching as opposed to teacher presence (Vlachopoulos \& Cowan, 2010). Each presence includes a sequence of stages, the interactions of which at different instances in the learning process propel the process forward and lead to deep learning experiences. For instance, within CP, while students can get through the first two stages (triggering event and exploration), TP is needed for the completion of the last two stages (integration and resolution), thereby suggesting a complementary relationship between TP and SP (Garrison \& Arbaugh, 2007). Research also shows that there is a strong relationship between SP and learning outcomes (Hwang \& Arbaugh, 2006) and that SP forms the foundation of CP (Garrison \& Arbaugh, 2007) and mediates between TP and CP (Garrison, 2017). Post a series of empirical studies (Shea \& Bidjerano, 2010; Shea et al., 2012; Shea et al., 2013) Shea and colleagues proposed the inclusion of a new construct, that is, learning presence (LP) in the CoI framework.

Garrison (2017) provides a comprehensive account of the research and developments in the CoI framework to date acknowledging the need for further exploration and validation. In terms of structural evaluation of a CoI, since SP is the underlying presence of CP and TP, SP is always present in a CoI. SP is represented by group cohesion or the level of interactions between participants (Garrison, 2017). Therefore, the overall density and distribution of interactions of the network underlying a CoI represents the distribution of SP and potentially $\mathrm{CP}$ and/or TP. Hence, we believe that the first step in an assessment of a $\mathrm{CoI}$ must include examination of the configuration of interactions (SP) between participants.

\section{The Systematic Review Process}

\section{Methods}


"A systematic literature review is a means of identifying, evaluating, and interpreting all available research relevant to a particular research question, or topic area, or phenomenon of interest" (Kitchenham, 2004, p.1). A systematic review is different from a traditional literature review in that it follows a scientific methodology and should be replicable (Staples \& Niazi, 2007). The overall structure of this review follows Kitchenham's (2004) guidelines which have been adapted to the educational context as has been done before (Cela et al., 2015). As per the guidelines, we begin by identifying the need for the review. Then we present the review protocol which includes the scope and research questions. Next, we describe identification of research studies including the database searches and study selection criteria and process. Finally, we synthesize and report our findings.

\section{Identifying the Need for a Systematic Review}

Prior to conducting a systematic literature review a search should be undertaken for any existing relevant reviews that might address the subject under review thereby eliminating the need for the review (Staples \& Niazi, 2007). At the time the original database searches were conducted in March 2017, we found one prior systematic literature review on SNA in e-learning (Cela et al., 2015) which mentions two other previous reviews (Sie et al., 2012; Zhao, Zhu, \& Wu, 2011) on SNA. A rerun of the database searches in May 2018 identified another literature review (Dado \& Bodemer, 2017) that examines trends in the application of SNA for investigating learner interactions in computersupported collaborative learning environments. None of the reviews make any mention of the CoP and/or CoI frameworks. Literature reviews on CoP (Smith et al., 2017) and CoI (Rourke \& Kanuka, 2009) also make no mention of the studies that use SNA as a key analytical methodology.

\section{Review Protocol}

Defining the focus of the review. The most critical component of a systematic literature review is the set of research questions driving the review, as they define the boundaries of the review and impact the inclusion criteria for studies (Staples \& Niazi, 2007). This review was conducted to address the following research questions:

RQ1: Which research studies in HEOL employ SNA to investigate a CoP and CoI?

RQ2: Which SNA constructs have been used to explore components of a CoP and CoI?

RQ3: What other complementary analytical techniques have been used with SNA?

RQ4: How effective is SNA for investigating and identifying a CoP and CoI?

RQ5: What limitations have been identified and what suggestions for further research have been made in existing studies?

Searching literature databases. Database searches were conducted in March 2017 and again in May 2018 in EBSCOhost, SCOPUS, and ERIC. SCOPUS is the largest database of peer-reviewed research literature, ERIC is one of the most used databases for education-related literature and, the EBSCOhost platform includes numerous databases across multiple disciplines. The search criteria consisted of combinations of different terms to ensure maximum coverage of variations in usage (see Table 1). The search was conducted on the full text of documents and was limited to peer-reviewed journal articles in English. No lower limit on the year of publication was specified.

Table 1.

Database Search Terms 
Term

Online Learning

Community

Community of Practice

Community of Inquiry

Higher Education

Social Network Analysis

\section{Variations}

e-learning OR elearning OR online learning OR blended

learning

community OR communities

community of practice OR communities of practice

community of inquiry OR communities of inquiry

undergraduate OR graduate OR postgraduate OR bachelors

OR masters OR higher education

social network analysis

Study selection. The search process began with specifying broad criteria which were progressively narrowed down to include studies in HEOL that use SNA as an analytical tool and use $\mathrm{CoP}$ and/or CoI as key frameworks for analysis. Table 2 below shows the different stages of the study selection process. The numbers shown in the table represent studies in HEOL as this was applied as an umbrella criterion for the searches.

Table 2 .

Study Selection Process

\begin{tabular}{|lllll|}
\hline \multicolumn{5}{|l|}{ Search Parameters } \\
\hline Stage 1 & Stage 2 & Stage 3 & \\
\hline Databases & Community & $\begin{array}{l}\text { Community } \\
\text { \& SNA }\end{array}$ & CoP \& SNA & CoI \& SNA \\
\hline SCOPUS & 12,712 & 441 & 126 & 83 \\
EBSCO Host & 2,247 & 11 & 2 & 1 \\
ERIC ProQuest & 2,085 & 109 & 63 & 173 \\
\hline Total & $\mathbf{1 7 , 0 4 4}$ & $\mathbf{5 6 1}$ & $\mathbf{1 9 1}$ & $\mathbf{1 0 2}$ \\
\hline & Stage 4 & $\begin{array}{l}\text { Bogus results } \\
\text { \& Duplicates }\end{array}$ & 12 & 5 \\
\hline Stage 5 & $\begin{array}{l}\text { Remaining } \\
\text { Studies } \\
\text { Abstracts } \\
\text { searched for } \\
\text { SNA }\end{array}$ & 180 & 98 \\
\hline & & 37 & 29 \\
\hline
\end{tabular}

Stage 1 of the search returned a total of 17,044 studies in HEOL mentioning the term "community." In Stage 2, the search criteria were further narrowed to include "social network analysis," returning a total of 561 studies. In Stage 3, the criteria were again narrowed, and two separate searches were conducted to include "community of practice" and "community of inquiry" returning a total of 191 studies mentioning CoP and SNA and 102 studies mentioning CoI and SNA. In Stage 4, bogus results and duplicates were removed. In Stage 5, with the assumption that studies using SNA as an analytical methodology would mention the term "network analysis" in their abstracts, the abstracts of the remaining $180 \mathrm{CoP}$ studies and $98 \mathrm{CoI}$ studies were searched for the term. Finally, $37 \mathrm{CoP}$ studies and $29 \mathrm{CoI}$ studies were selected for a detailed review. Upon detailed review, of the 37 studies using SNA and the CoP framework, 19 were either not using SNA or were 
not in HEOL, 6 only mentioned the CoP framework, 1 was a literature review, and 10 were duplicates of the CoI studies. Therefore, finally only 1 study met the inclusion criteria. Of the 29 studies using SNA and the CoI framework, 7 were not in HEOL, 12 only mentioned the CoI framework and, 1 was a literature review. Therefore, finally 9 studies met the inclusion criteria. There are many examples of the application of SNA on the use of social media in online learning (e.g. Veletsianos \& Kimmons, 2016). All such studies have been excluded from the review as our focus is on formal and structured learning within a LMS.

Other searches. To extend the scope of the search, references of the selected studies were reviewed. Additionally, the citation index of the studies was obtained using Google Scholar (https://scholar.google.com.au). Upon review, none of the studies citing the selected studies met the inclusion criteria. Furthermore, selected authors were contacted for further information. No additional studies were identified.

\section{Results}

\section{RQ1: Which research studies in HEOL employ SNA to investigate a CoP and CoI?}

Table 3 lists the studies included in this systematic review. Each study has been assigned a number for ease of reference. A detailed summary of the studies is provided in Appendix A.

Table 3.

SNA and CoP/CoI Studies

\begin{tabular}{|c|c|c|c|c|}
\hline No. & Author(s) & Year & Framework & Title \\
\hline S1 & Shea \& Bidjerano & 2010 & $\mathrm{CoI}$ & $\begin{array}{l}\text { A re-examination of the community } \\
\text { of inquiry framework: Social network and } \\
\text { content analysis }\end{array}$ \\
\hline $\mathrm{S} 2$ & Annese \& Traetta & 2012 & $\mathrm{CoP}$ & $\begin{array}{l}\text { Distributed participation in blended } \\
\text { learning communities: Actors, contexts, } \\
\text { and groups }\end{array}$ \\
\hline $\mathrm{S} 3$ & $\begin{array}{l}\text { Jimoyiannis, } \\
\text { Tsiotakis, \& } \\
\text { Roussinos }\end{array}$ & 2012 & $\mathrm{CoI}$ & $\begin{array}{l}\text { Blogs in higher education: Analysing students' } \\
\text { participation and presence in a community of } \\
\text { blogging }\end{array}$ \\
\hline $\mathrm{S} 4$ & Shea et al. & 2013 & $\mathrm{CoI}$ & $\begin{array}{l}\text { Online learner self-regulation: Learning presence } \\
\text { viewed through quantitative content- and social } \\
\text { network analysis }\end{array}$ \\
\hline S5 & Shea et al. & 2014 & $\mathrm{CoI}$ & $\begin{array}{l}\text { Re-conceptualizing the community of inquiry } \\
\text { framework: An exploratory analysis }\end{array}$ \\
\hline S6 & $\begin{array}{l}\text { Tirado, } \\
\text { Hernando, \& } \\
\text { Aguaded }\end{array}$ & 2015 & $\mathrm{CoI}$ & $\begin{array}{l}\text { The effect of centralization and cohesion on the } \\
\text { social construction of knowledge in discussion } \\
\text { forums }\end{array}$ \\
\hline S7 & Wicks et al. & 2015 & $\mathrm{CoI}$ & $\begin{array}{l}\text { An evaluation of low versus high collaboration in } \\
\text { online learning }\end{array}$ \\
\hline S8 & $\begin{array}{l}\text { Jimoyiannis \& } \\
\text { Tsiotakis }\end{array}$ & 2017 & $\mathrm{CoI}$ & $\begin{array}{l}\text { Beyond students' perceptions: Investigating learning } \\
\text { presence in an educational blogging community }\end{array}$ \\
\hline
\end{tabular}




\begin{tabular}{|lllll|}
\hline S9 & Jo, Park, \& Lee & 2017 & CoI & $\begin{array}{l}\text { Three interaction patterns on asynchronous online } \\
\text { discussion behaviours: A methodological } \\
\text { comparison }\end{array}$ \\
S10 & Satar \& Akcan & $2018 \quad$ CoI & $\begin{array}{l}\text { Pre-service EFL teachers' online participation, } \\
\text { interaction, and social presence }\end{array}$ \\
\hline
\end{tabular}

Of the 10 studies, all except one (S2) were conducted in the context of the online space of online or blended courses. S2 explored online and off-line interactions. The studies investigated interactions within asynchronous discussion forums (S1, S2, S4, S5, S6, S9, S10), blogs (S3, S7, S8) and journal entries (S4). All investigations were conducted on interactions between students and/or tutors. The key objective of each study guided the scope and nature of analysis undertaken. S1 conducted an examination of the relationships between CP, SP and TP; S2 investigated the impact of learning design on participation in a CoP; S3 analyzed student participation in terms of $\mathrm{CP}$, SP, and TP; S4 conducted an exploration of LP and network positions and the effects of assigning instructional roles to students on LP and network positions; S5 investigated relationships between LP and CP, SP and TP, and explored the impact of assigning instructional roles to students; S6 developed a model to verify the influence of cohesion and centralization on the quality of the learning process; S7 investigated the impact of student collaboration on student performance; S8 developed an integrated framework for designing and investigating engagement patterns and LP; S9 conducted a comparison of three analytical methodologies to assess the quality of online discussions and their relationship with academic performance and; S10 examined the relationship between online participation, interaction, and SP levels.

\section{RQ2: Which SNA constructs have been used to explore components of a CoP and CoI?}

Network properties. A network is made of nodes and interconnections between them (Wasserman \& Faust, 1994). A one-mode network comprises of a single set of nodes connected by single or multiple types of relationships. A two-mode network consists of two sets of nodes, that is, actors and events (Scott, 2000). All included studies were on one-mode networks. Nodes in a network can represent human and/or non-human entities. All included studies comprised of human entities where the nodes represented students only (S2, S3, S4, S5, S6, S7, S8, S9) or students and tutor (S1, $\mathrm{S} 10$ ). The number of nodes determine the size and boundaries of a network (Wasserman \& Faust, 1994). Of the 10 studies, three (S2, S4, S5) had less than 25 nodes, five studies (S3, S6, S7, S9, S10) had between 35 to 75 nodes and two studies $(\mathrm{S} 1, \mathrm{~S} 9)$ did not specify the number of nodes.

A tie or link between nodes in a network represents the relationship between the nodes which can be of any type, for instance, co-workers, friends, professionals, etc. (Wasserman \& Faust, 1994). The direction of a tie identifies the initiator of the relationship, a bi-directional tie represents a reciprocal relationship while the weight of a tie signifies the strength of the relationship (Borgatti et al., 2013). The ties in the selected studies represented interactions between students and/or tutors or lecturers. Of the 10 studies, eight used directed and un-weighted networks. The networks in S6 and S10 were directed and weighted.

SNA, CoP and CoI constructs. The majority of the studies used similar SNA measures. Here we discuss the key SNA measures used along with corresponding structural components of a CoP and CoI. For a detailed analysis, see Appendix B.

A network can be measured in terms of its shape and cohesion. Determinants of cohesion include a networks' centralization, density, and number and size of cliques. Centralization, a shape 
measure, is defined as the degree to which a single node dominates a network (Borgatti et al., 2013). In S6, the network's centralization is used as a measure of collective communication and overall cohesion of a CoI, while S10 interprets centralization in terms of the existence of SP in the CoI. Density, which is calculated by dividing the total number of ties in a network by the total number of possible ties, is a proportion, therefore, it allows for comparison of networks regardless of size assuming the size differential is not huge (Borgatti et al., 2013). In S1 and S10, density is taken as an indicator of SP; S6 and S9 use density to assess rate of participation in a CoI, and S2 uses the measure of density to assess the participation trajectory of the CoP.

In a large complex network, often there are nodes within sub-groups that have a higher density of connections that warrant detailed analysis as independent entities. These sub-groups are called cliques. A clique is a group of nodes in which every node is adjacent to every other node in the group, that is, it is a maximally connected sub-network with a density of 1 . S3 and S8 use clique analysis to investigate the overall architecture of a CoI taking the number and composition of cliques as determinants of the process of knowledge creation and extent of communication. S2 examines cliques to assess the development of the $\mathrm{CoP}$ and individual learning trajectories. Cliques can overlap which means a node can belong to multiple cliques and there can be nodes that do not belong to any clique (Borgatti et al., 2013). Nodes belonging to multiple cliques are considered as bridges or brokers. S2 uses clique analysis to identify brokers and assess local and global interactions within and across subgroups.

The centrality of a node refers to the structural position of the node in a network. The simplest measure of centrality is degree centrality which is the number of connections of a node. In a directed network, the in-degree centrality measures the incoming edges and the out-degree centrality represents outgoing edges. The centrality of a node has also been linked to power, influence, prestige, and performance (Borgatti et al., 2013). In-degree centrality and out-degree centrality were used as indicators of influence and prestige (S1, S5) linked to CP, TP and CP and LP (S4, S5, S7) in a CoI. Overall degree centrality was used to signify status and roles in a CoP (S2) and power in terms of spreading information and influencing others in a $\mathrm{CoI}(\mathrm{S} 3, \mathrm{~S} 8)$.

Summarizing, we have found that at the whole network level, measures of cohesion have dominated the structural evaluation of a $\mathrm{CoP}$ and $\mathrm{CoI}$ and at the individual node level, measures of degree centrality have been prominent.

\section{RQ3: What other complementary analytical techniques have been used with SNA?}

Other complementary techniques used in the studies include content analysis, critical discourse analysis and statistical analysis like correlations, multiple regressions, non-parametric tests of significance and structured equation modeling. Content analysis is a qualitative and quantitative analytical technique used to conduct an in-depth analysis of discussion transcripts enabling standardized interpretations and classifications of text according to a specific coding scheme (de Wever, Schellens, Valcke, \& Van Keer, 2006). Critical discourse analysis is a special technique grounded in critical linguistics and critical semiotics, used to examine written text and the language, discourse, or communication within the text (Van Dijk, 1995). A list of complementary techniques used by each study are listed in Appendix B. Clearly, to date, SNA has not been used as a stand-alone technique in the investigation of a $\mathrm{CoP}$ or $\mathrm{CoI}$.

\section{RQ4: How effective is SNA for investigating and identifying a CoP and CoI?}


The overall objective of this systematic review which was to tease out how structural components of a CoP and CoI have been researched using SNA. To assess the effectiveness of SNA for investigating a $\mathrm{CoP}$ and $\mathrm{CoI}$, a synthesis of findings from the studies follows.

Community of inquiry. Four of the CoI studies examined SNA indicators of CP, TP and SP and the relationship between the presences. In an exploration of the relationship between $\mathrm{CP}, \mathrm{SP}$ and $\mathrm{TP}$ in an online discussion forum, S1 found in-degree to be a poor indicator of CP, especially when applied to the tutor. In other words, incoming comments to the tutor were not of educational value. However, the out-degree centrality of the tutor was associated with initiation of productive exchange, a category of CP. The study reported density to be a good indicator of SP. In line with findings of S1, S6 found SP to be more prominent as compared to CP in an online discussion forum. However, structured equation modeling showed a positive relationship between network centralization and SP as well as CP. Similarly, in an online blogging community, S3 found a positive association between $\mathrm{CP}$, knowledge construction, and active participation in the community. In this instance, $\mathrm{CP}$ was found to be higher than TP and SP. S10 reported inconclusive findings on the relationship between centrality, density, and SP in an online discussion forum. In a methodological comparison, S9 found combined $\mathrm{CP}$ and in-degree centrality to be a significant predictor of academic performance, thereby corroborating the positive relationship between the two.

Four of the CoI studies explored the construct of LP and its relationship with degree centrality and CP, SP, and TP. For instance, in a discussion forum, S4 found that key student facilitators with high degree centralities exhibited higher levels of LP. In general, findings suggested that students with high LP also had high in-degree implying that they were considered valuable sources of information by other students. In a follow-up study, which investigated the relationships between LP and CP and SP and TP, S5 found no significant correlation between TP and degree centrality however, LP and CP and, LP and degree centrality were positively associated with degree centrality. Similarly, S8 applied hierarchical clustering to group similar students and found an association between degree centrality and LP in an online blogging community. Likewise, investigating the impact of collaboration on learning, S7 reported a positive correlation between LP and out-degree and a negative correlation between LP and in-degree. Findings of these studies point to a positive relationship between LP and degree centrality however, at this point there is not enough published research to validate the construct of LP and its relationship with the other three presences.

Considering that the $9 \mathrm{CoI}$ studies report disparate findings in terms of the relationship between degree centralities and CP, SP and TP, SNA's capacity to identify the type of presence based on overall and in and out-degree centralities of participants of a CoI cannot be established. However, if SP is the underlying presence in a CoI which gradually evolves into $\mathrm{CP}$ and $\mathrm{TP}$ over time (Garrison, 2017), it is reasonable to assume that the density of network and overall degree centrality of a node is indicative at least of SP upon which TP and CP develop.

Communities of practice. S2 presents findings of action research on the impact of learning design on student participation and collaboration in a blended course. The researchers base their analysis on a comparison of individual and group participation trajectories within sub-group (local) and whole network (global) interactions. They use measures of density and cohesion as indicators of the global trajectory of the community. For individual trajectories, degree centralities and the number and structure of cliques are analyzed where overlapping cliques represent overlapping CoP. At the same time, the status and role of brokers and bridges are considered within the local and global community. In their discussion of the findings, the researchers place emphasis on the rhythm between local and global interactions and the effect of this rhythm on the sense of belonging to individual sub- 
groups and the whole community. The researchers attribute the online togetherness to the mediating role played by the technological artefact, the LMS, which brings students together. The researchers conclude that the design of the course led to the development of a CoP without spatial or temporal boundaries in which the rhythms of participation amplify the shared repertoire and sustain the mutual engagement and joint enterprise as indicated by an increase in global cohesion over time. S2 provides a very good, albeit only one, example of how SNA can be effectively used to investigate structural components of a CoP in HEOL. This example, coupled with the fact that SNA has been used considerably in conjunction with the CoP framework in other contexts (e.g. Grandjean, 2016; Lee, $\mathrm{Kim}, \& \mathrm{Su}, 2014$ ) leads us to conclude that SNA can be used effectively in a structural evaluation of a CoP.

\section{RQ5: What limitations have been identified and what suggestions for further research have been made in existing studies?}

Even though the sample size of majority of the studies is small, only two studies (S5, S6) explicitly state it as a limitation. More specifically, several studies (S1, S2, S3, S6, S8, S10) point out the need to investigate the role of tutors/facilitators and its impact on participation dynamics. Another important suggestion for further research $(\mathrm{S} 3, \mathrm{~S} 8)$ is the need to explore the influence of student characteristics like cognitive needs, goals, learning habits, and motivation on participation. Other suggestions include focusing on a specific part of the learning process, for instance, the role of a technological artefact (S2), extending analysis to off-line interactions for blended units (S8, S10), identification of variables in discussion transcripts that are indicative of quality of learning (S9), validation of the coding scheme for content analysis (S1, S6), application of other SNA measures besides centrality and examination of multiple overlapping social networks (S7), exploration of the relationship between learning outcomes and centralities (S7) and, exploration of characteristics of lurkers or observers (S8). In general, findings of the selected studies are not generalizable as they are limited to the participants and the context they were conducted in, therefore, to validate the findings, the studies need to be replicated in other contexts.

\section{Discussion}

There is plenty of stand-alone research using SNA, the CoP and the CoI frameworks in HEOL. However, as we have found, there are a very limited number of studies that bring together constructs from SNA and these community-based frameworks. Therefore, this review provides a valuable synthesis of research that integrates SNA and the CoP and CoI frameworks in HEOL. There are three major themes that emerge from this systematic literature review.

Firstly, the review has revealed that for studies using SNA with the CoI framework, findings are mixed in terms of the effectiveness of SNA to identify the different presences in a CoI. For instance, $\mathrm{S} 1$ reported no association between degree centrality and $\mathrm{CP}$ in a discussion forum whereas, $\mathrm{S} 3$ found a positive relation between the two constructs in a blogging community. Therefore, overall and in and out-degree centralities cannot reliably be correlated with a particular presence in a CoI, thereby necessitating complementing SNA with a qualitative analytical technique such as content analysis as was done in the studies included in the review. Similarly, the one study (S2) integrating SNA with the CoP framework provides one example of the effectiveness of SNA in identifying the structural dynamics of the community and individuals within, however, a complete exploration of a CoP calls for combining SNA with qualitative analysis. Furthermore, the studies support the use of other statistical techniques like correlation and regression analysis, along with SNA and qualitative 
analysis, to determine significance of relationships between SNA constructs and components of a CoI and CoP. Clearly, at this point, as a stand-alone technique, SNA has not been shown to have the capacity to identify a CoI or CoP structurally. However, by isolating key sub-groups and participants, SNA does prove to be an effective filter for big data thereby reducing complexity of the data.

Secondly, we would like to bring to the forefront concerns about the untapped potential of SNA. None of the included studies consider how SNA can be used to identify a CoI or a CoP based on the overall structural characteristics of the underlying network. For instance, can we say that a highly centralized network represents a CoP? Or is it a CoI? Considering that the frameworks are conceptually distinct, should we expect different network structures underlying each? If so, with regard to higher education, if we assume achievement in a course signifies learning, is there a direct correlation between learning within a $\mathrm{CoP}$ or $\mathrm{CoI}$ ? Is there a qualitative difference in the way students learn within a CoP and CoI? Are there other SNA measures that might be more appropriate for evaluating a $\mathrm{CoI}$ and $\mathrm{CoP}$ ? Considering network visualizations, can a $\mathrm{CoP}$ and $\mathrm{CoI}$ be identified visually?

Thirdly, we would like to highlight the lack of consideration to students' attributes and performance in the selected studies. None of the studies consider student attributes and only two (S7, S10) examine how interactions translate into performance. In the context of higher education, if we accept that final grade is an indication of learning, what can this tell us about students' learning in a $\mathrm{CoP}$ or CoI? Years of research shows that communities are effective in fostering deep learning, but how can we explain a scenario in which if a student who appears as a well-connected node in the community does not perform as well as another student who is on the periphery? One explanation could be provided by examining student attributes like self-efficacy and goal orientation and their influence on participation and performance. Therefore, a holistic investigation of learning within communities warrants inclusion of attributional variables.

\section{Conclusion}

In view of the significance of community-based learning and its relevance to HEOL, the motivation for conducting this review came from the heavy reliance on qualitative analysis in research involving the $\mathrm{CoP}$ and $\mathrm{CoI}$ frameworks, which are increasingly being applied by researchers and practitioners of HEOL. The key objective of the review was to assess the efficacy of a quantitative technique, SNA, for evaluating and identifying a CoP and CoI based on structural components of each. The review reveals the dearth of research studies in HEOL that use SNA with the CoP and CoI frameworks thereby pointing to the inadequacy of research in the area. Our findings show that the small number and disparate results of the selected studies do not validate a correspondence between a specific SNA measure and a CoP or CoI structural component. However, repeated use of some SNA measures justifies further validation and therefore inclusion of these measures in future studies involving the $\mathrm{CoP}$ and $\mathrm{CoI}$ frameworks. Also, we believe that the potential of SNA to structurally evaluate and identify a $\mathrm{CoP}$ and $\mathrm{CoI}$ remains untapped as a limited number of SNA measures have been used and the power of network visualizations has not been considered.

Considering the lack of literature found, the review highlights the need for further studies in HEOL that integrate SNA with the CoP and CoI frameworks and address aforementioned gaps in existing research. In terms of limitations, in line with our focus on pedagogical practices within a LMS, this review was limited to studies involving interactions within the LMS in the context of HEOL. Furthermore, the review was restricted to peer-reviewed journal articles in English therefore, 
it does not consider investigations that might have been published in conference papers and book chapters, etc. or in other languages.

In conclusion, we recommend the development of a fully integrated methodological framework including SNA measures and structural components of the CoP and CoI frameworks. Not only would such a framework reduce reliance on extensive qualitative analysis, it would allow for an examination of the relationships between student attributes, participation, and learning. As such, the framework would present useful practical implications for practitioners, researchers and even students. Furthermore, by providing theoretical foundations to SNA measures, the framework would also address the concerns about the lack of theoretical grounding in research involving SNA (De Laat, 2014: Hamilton \& Feenberg, 2005).

\section{Acknowledgements}

The research has been funded through the Macquarie University Research Excellence Scholarship. 


\section{References}

Acharjya, D. P., \& Ahmed, K. P. (2016). A survey on big data analytics: Challenges, open research issues and tools. International Journal of Advanced Computer Science and Applications, $7(2), 511-518$.

Allen, I, E., Seaman, J., Poulin, R. and Straut, T. T. (2016). Online report card: Tracking online education in the United States. Retrieved from http://onlinelearningsurvey.com/reports/onlinereportcard.pdf

Annese, S., \& Traetta, M. (2012). Distributed participation in blended learning communities: Actors, contexts and groups. International Journal of Web Based Communities, 8(4), 422-439. doi:10.1504/IJWBC.2012.049558.

Avella, J. T., Kenritchi, M., Nunn, S. G., \& Kanai, T. (2016). Learning analytics methods, benefits, and challenges in higher education: A systematic literature review. Online Learning, (20)2, 13-29.

Aviv, R., Erlich, Z, Ravid, G., \& Geva, A. (2003). Network analysis of knowledge construction in asynchronous learning networks. Journal of Asynchronous Learning Networks, 7(3), 1-23.

Biza, I., Jaworski, B., \& Hemmi, K. (2014). Communities in university mathematics. Research in Mathematics Education, 16(2), 161-176. doi:10.1080/14794802.2014.918351.

Borgatti, S. P., Everett, M. G., \& Johnson, J. C. (2013). Analyzing social networks. SAGE Publications. Kindle Edition. Retrieved from Amazon.com.

Chambers, D., Wilson, P., Thomson, C., Harden, M. (2012). Social network analysis in healthcare: A systematic scoping review. PloS ONE, 7(8), e41911. doi:10.1371/journal.pone.0041911.

Cela, K. L., Sicilia, M. A., \& Sanchez, S. (2015). Social network analysis in e-learning environments: A preliminary systematic review. Educational Psychology Review, 27, 219246. doi:10.1007/s10648-014-9276-0.

Conole, G., Galley, R., \& Culver, J. (2011). Frameworks for understanding the nature of interactions, networking, and community in a social networking site for academic practice. International Review of Research in Open and Distance Learning, 12(3), 119 - 138.

Cross, R., Laseter, T., Parker, A. \& Velasquez, G. (2006). Using social network analysis to improve communities of practice. California Management Review, 49(1), 32-60. doi: $10.2307 / 41166370$.

Dado, M. \& Bodemer, D. (2017). A review of methodological applications of social network analysis in computer-supported collaborative learning. Educational Research Review, 22, 159-180.

De Laat, M., \& Prinsen, F. R. (2014). Social learning analytics: Navigating the changing settings of higher education. Research \& Practice in Assessment, 9, 51 - 60.

http://hdl.handle.net/1820/5870

Dewey, J. (1938). Experience and education. New York: Simon \& Schuster.

De Wever, B., Schellens, T., Valcke, M. \& Van Keer, H. (2006). Content analysis schemes to analyze transcripts of online asynchronous discussion groups: A review. Computers \& Education, 46(1), $6-28$. 
Freeman, L. C. (2006). The development of social network analysis. Vancouver, Canada: Empirical Press. Gilbert.

Garrison, D. R. (2017). E-learning in the 21st Century. New York and London: Routledge.

Garrison, D. R., Anderson, T., \& Archer, W. (2000). Critical inquiry in a text-based environment: Computer conferencing in higher education. The Internet and Higher Education, 2(2-3), 87105. doi: 0.1016/S1096-7516(00)00016-6.

Garrison, D. R., Anderson, T., \& Archer, W. (2001). Critical thinking, cognitive presence, and computer conferencing in distance education. American Journal of Distance Education, 15(1), 7-23. doi:10.1080/08923640109527071.

Garrison, D. R., \& Arbaugh, J. B. (2007). Researching the community of inquiry framework: Review, issues, and future directions. Internet and Higher Education, 10, 157 - 172. doi:10.1016/j.iheduc.2007.04.001.

Garrison, D. R., \& Kanuka, H. (2004). Blended learning: Uncovering its transformative potential in higher education. Internet and Higher Education, 7, 95-105. doi:10.1016/j.iheduc.2004.02.001.

Grandjean, M. (2016). A social network analysis of Twitter: Mapping the digital humanities community. Cogent Arts and Humanities, 3(1). doi:10.1080/23311983.2016.1171458

Granovetter, M. (2005). The impact of social structure on economic outcomes. The Journal of Economic Perspectives, 19(1), 33-50. doi:10.1257/0895330053147958.

Hamilton, E., \& Feenberg, A. (2005). The technical codes of online education. Techné: Research in Philosophy and Technology, 9(1).

Hwang, A. \& Arbaugh, J. B. (2006). Virtual and traditional feedback-seeking behaviours: Underlying competitive attitudes and consequent grade performance. Decision Sciences Journal of Innovative Education, 4, 1-28. doi:10.1111/j.1540-4609.2006.00099.x

Haythornthwaite, C. (1996). Social network analysis: An approach and technique for the study of information exchange. Library and Information Science Research 18, 323-342. doi:10.1016/s0740-8188(96)90003-1.

Jimoyiannis, A., Tsiotakis, P., \& Roussinos, D. (2012). Blogs in higher education: Analysing students' participation and presence in a community of blogging. Paper presented at the Proceedings of the IADIS International Conference e-Learning 2012.

Jimoyiannis, A., \& Tsiotakis, P. (2017). Beyond students' perceptions: investigating learning presence in an educational blogging community. Journal of Applied Research in Higher Education, 9(1), 129-146. doi:10.1108/JARHE-06-2015-0046.

Jo, I., Park, Y., \& Lee, H. (2017). Three interaction patterns on asynchronous online discussion behaviours: A methodological comparison. Journal of Computer Assisted Learning, 33(2), 106-122. doi:10.1111/jcal.12168

Kitchenham, B. (2004). Procedures for Performing Systematic Reviews (Keele University. Technical Report TR/SE-0401).

LAK. (2011). $1^{\text {st }}$ International conference on learning analytics and knowledge. Retrieved from https://tekri.athabascau.ca/analytics/ 
Lave, J. \& Wenger, E. (1991). Situated learning: Legitimate peripheral participation. Cambridge: Cambridge University Press. doi:10.1017/CBO9780511815355

Lee, S., Kim, Y. S., \& Suh, E. (2014). Structural health assessment of communities of practice (CoPs). Journal of Knowledge Management, 18(6), 1198-1216. doi:10.1108/JKM-11-20130454

Moreno, J. L. (1953). Sociometry. Journal of Interpersonal Relations and Experimental Design, $18(4)$.

Nistor, N., \& Fischer, F. (2012). Communities of practice in academia: Testing a quantitative model. Learning, Culture and Social Interaction, 1(2), 114-126. doi.org/10.1016/j.lcsi.2012.05.005

Palloff, R., \& Pratt, K. (1999). Building learning communities in cyberspace. San Francisco: JosseyBass.

Picciano, A.G. (2012). The evolution of big data and learning analytics in American higher education. Journal of Asynchronous Learning Networks, 16(3), 9-20.

Rourke, L., \& Kanuka, H. (2009). Learning in communities of inquiry: A review of literature. Journal of Distance Education, 23(1), 19-48.

Satar, H. M., \& Akcan, S. (2018). Pre-service EFL teachers' online participation, interaction, and social presence. Language Learning \& Technology, 22(1), 157-183.

Scott, J. (2000). Social network analysis: a handbook. London: Sage.

Senghore, F., Campos-Nanez, E., Fomin, P., \& Wasek, J. S. (2014). Using social network analysis to investigate the potential of innovation networks: Lessons learned from NASA's international space apps challenge. Procedia Computer Science, 28, 380 - 388.

doi:10.1016/j.procs.2014.03.047

Shea, P. \& Bidjerano, T. (2010). A re-examination of the community of inquiry framework: Social network and content analysis. Internet and Higher Education, 13, 10-21. doi:10.1016/j.iheduc.2009.11.002

Shea, P., Hayes, S., Smith, S. U., Vickers, J., Bidjerano, T, Pickett, A., ..., Jian, S. (2012). Learning presence: Additional research on a new conceptual element within the community of inquiry (CoI) framework. Internet and Higher Education, 15(2), 89-95.

doi:10.1016/j.iheduc.2011.08.002

Shea, P., Hayes, S., Smith, S. U., Vickers, J., Bidjerano, T, Gozza-Cohen, M., ..., Tseng, C. (2013). Online learner self-regulation: Learning presence viewed through quantitative content- and social network analysis. International Review of Research in Open and Distributed Learning, 14(3), 427-461. doi:10.19173/irrodl.v14i3.1466

Shea, P., Hayes, S., Uzuner-Smith, S., Gozza-Cohen, M., Vickers, J., \& Bidjerano, T. (2014). Reconceptualizing the community of inquiry framework: An exploratory analysis. Internet and Higher Education, 23, 9-17. doi:10.1016/j.iheduc.2014.05.002

Sie, R. L., Ullmann, T. D., Rajagopal, K., Cela, K., Bitter-Rijpkema, M., \& Sloep, P. B. (2012). Social network analysis for technology-enhanced learning: review and future directions. International Journal of Technology Enhanced Learning, 4(3), 172-190. doi:10.1504/IJTEL.2012.051582. 
Smith, B. L. (2001). The challenge of learning communities as a growing national movement. Association of American Colleges \& Universities Peer Review, 4(1).

Smith, S. U., Hayes, S., \& Shea, P. (2017). A critical review of the use of Wenger's community of practice (CoP) theoretical framework in online and blended learning research, 2000-2014. Online Learning, 21(1), 209-237. doi:10.24059/olj.v21i1.963.

Staples, M., \& Niazi, M. (2007). Experiences using systematic review guidelines. Evaluation and Assessment in Software Engineering EASE06, 80(9), 1425-1437. doi:10.1016/j.jss.2006.09.046

Tirado, R., Hernando, Á., \& Aguaded, J. I. (2015). The effect of centralization and cohesion on the social construction of knowledge in discussion forums. Interactive Learning Environments, 23(3), 293-316. doi:10.1080/10494820.2012.745437

Van Dijk, T. A. (1995). Aims of critical discourse analysis. Japanese Discourse, 1, 17-27.

Veletsianos, G., \& Kimmons, R. (2016). Scholars in an increasingly open and digital world: How do education professors and students use Twitter? The Internet and Higher Education, 30, 1-10. doi:http://dx.doi.org/10.1016/j.iheduc.2016.02.002

Vlachopoulos, P., \& Cowan, J. (2010). Reconceptualising moderation in asynchronous online discussions using grounded theory. Distance Education, 31(1), 23-36. doi: $10.1080 / 01587911003724611$

Vygotsky, L. S. (1978). Mind and society. Cambridge, MA: Harvard University Press.

Ward, W. D., Stovel, K., \& Sacks, A. (2011). Network analysis and political science. Annual Review of Political Science, 14, 245 - 264. doi:10.1146/annurev.polisci.12.040907.115949

Wasserman, S., \& Faust, K. (1994). Social network analysis. Cambridge University Press. https://doi.org/10.1017/cbo9780511815478

Wenger, E. (1998). Communities of practice: Learning, meaning, and identity. New York, NY: Cambridge University Press. doi:10.1017/cbo9780511803932

Wenger, E., McDermott, R., \& Snyder, W. (2002). Cultivating communities of practice: A guide to managing knowledge. Cambridge, MA: Harvard Business School Press.

Wenger, E., White, N., \& Smith, J. (2009). Digital habitats: Stewarding technology for communities. Portland, OR: CPsquare.

Wenger, E., Trayner, B., \& de Laat, M. (2011). Promoting and assessing value creation in communities and networks: A conceptual framework. Rapport 18, Ruud de Moor Centrum, Open University of the Netherlands.

Wicks, D., Craft, B. B., Lee, D. D., Lumpe, A., Henrikson, R., Baliram, N., . . Wicks, K. (2015). An evaluation of low versus high collaboration in online learning. Journal of Asynchronous Learning, 19(4). doi: 10.24059/olj.v19i4.552.

Zhao, C., \& Kuh, G. D. (2004). Adding value: Learning communities and student engagement. Research in Higher Education, 45(2), 115-138. doi:10.1023/B:RIHE.0000015692.88534.de.

Zhao, Y., Zhu., Q., \& Wu, K. (2011). The development of social network analysis research in mainland China: a literature review perspective. In Proceedings of the 2011 iConference. ACM, pp. 296-303. 


\section{Appendix A}

\begin{tabular}{|c|c|c|c|c|c|c|}
\hline ID & $\begin{array}{l}\text { Author(s) } \\
\text { Year }\end{array}$ & Title & $\begin{array}{l}\text { Theoretical } \\
\text { Framework }\end{array}$ & Methodology & $\begin{array}{l}\text { Context / } \\
\text { Participants }\end{array}$ & Key Findings \\
\hline S1 & $\begin{array}{l}\text { Shea \& } \\
\text { Bidjerano } \\
(2010)\end{array}$ & $\begin{array}{l}\text { A re- } \\
\text { examination } \\
\text { of the } \\
\text { community } \\
\text { of inquiry } \\
\text { framework: } \\
\text { Social } \\
\text { network and } \\
\text { content } \\
\text { analysis }\end{array}$ & $\begin{array}{l}\text { Community } \\
\text { of inquiry } \\
(\mathrm{CP}, \mathrm{SP}, \mathrm{TP})\end{array}$ & $\begin{array}{l}\text { Content } \\
\text { analysis } \\
\text { SNA }\end{array}$ & $\begin{array}{l}\text { Online } \\
\text { learning } \\
2 \text { business } \\
\text { mgmt. courses } \\
\text { Discussion } \\
\text { forum } \\
\mathrm{n}=\text { not stated }\end{array}$ & $\begin{array}{l}\text { High tutor TP and SP } \\
\text { associated with higher levels } \\
\text { of student SP. Within CP, } \\
\text { triggering and reflection more } \\
\text { common than integration. } \\
\text { Centrality not a good } \\
\text { indicator of CP. Measures of } \\
\text { density align well with SP. }\end{array}$ \\
\hline S2 & $\begin{array}{l}\text { Annese \& } \\
\text { Traetta } \\
(2012)\end{array}$ & $\begin{array}{l}\text { Distributed } \\
\text { participation } \\
\text { in blended } \\
\text { learning } \\
\text { communities: } \\
\text { Actors, } \\
\text { contexts, and } \\
\text { groups }\end{array}$ & $\begin{array}{l}\text { Community } \\
\text { of practice }\end{array}$ & $\begin{array}{l}\text { Discussion } \\
\text { analysis } \\
\text { SNA }\end{array}$ & $\begin{array}{l}\text { Blended } \\
\text { learning } \\
3 \text { courses in } 3 \\
\text { academic } \\
\text { years } \\
\text { Online and } \\
\text { off-line } \\
\text { discussion } \\
\text { forums } \\
\mathrm{n}=10,15 \text { and } \\
23 \text {. }\end{array}$ & $\begin{array}{l}\text { Online participation more } \\
\text { cohesive before action than } \\
\text { off-line. After re- } \\
\text { organization, online and off- } \\
\text { line local discussions are } \\
\text { cohesive but not global } \\
\text { discussions. Online } \\
\text { discussion still more } \\
\text { cohesive. Global cohesion } \\
\text { increases with time. } \\
\text { Centrality is associated with } \\
\text { formal roles. }\end{array}$ \\
\hline S3 & $\begin{array}{l}\text { Jimoyiannis, } \\
\text { Tsiotakis, \& } \\
\text { Roussinos } \\
(2012)\end{array}$ & $\begin{array}{l}\text { Blogs in } \\
\text { higher } \\
\text { education: } \\
\text { Analysing } \\
\text { students' } \\
\text { participation } \\
\text { and presence } \\
\text { in a } \\
\text { community } \\
\text { of blogging }\end{array}$ & $\begin{array}{l}\text { Community } \\
\text { of inquiry } \\
(\mathrm{CP}, \mathrm{SP}, \mathrm{TP})\end{array}$ & $\begin{array}{l}\text { Content } \\
\text { analysis } \\
\text { SNA } \\
\text { Log-data } \\
\text { analysis }\end{array}$ & $\begin{array}{l}\text { Blended } \\
\text { learning } \\
\text { University } \\
\text { course } \\
\text { Blogs } \\
\mathrm{n}=48\end{array}$ & $\begin{array}{l}\text { Integration of ideas and } \\
\text { construction of meaning is } \\
\text { directly inferred from } \\
\text { students' participation. Blogs } \\
\text { can be implemented } \\
\text { effectively, within a blended } \\
\text { approach, to support students' } \\
\text { collaborative learning. High } \\
\text { participation indicative of CP. }\end{array}$ \\
\hline S4 & $\begin{array}{l}\text { Shea et al. } \\
\text { (2013) }\end{array}$ & $\begin{array}{l}\text { Online } \\
\text { learner self- } \\
\text { regulation: } \\
\text { Learning } \\
\text { presence } \\
\text { viewed } \\
\text { through } \\
\text { quantitative } \\
\text { content- } \\
\text { and social } \\
\text { network } \\
\text { analysis }\end{array}$ & $\begin{array}{l}\text { Community } \\
\text { of inquiry } \\
\text { (LP) }\end{array}$ & $\begin{array}{l}\text { Content } \\
\text { analysis } \\
\text { SNA }\end{array}$ & $\begin{array}{l}\text { Blended } \\
\text { learning } \\
\text { Doctoral } \\
\text { level course } \\
\text { Journals and } \\
\text { Discussion } \\
\text { forum } \\
\mathrm{n}=18\end{array}$ & $\begin{array}{l}\text { Insignificant differences in } \\
\text { LP, prestige and influence } \\
\text { of facilitators and non- } \\
\text { facilitators. Students } \\
\text { engaged in more reflection } \\
\text { in the journals. In } \\
\text { discussion, LP showed } \\
\text { moderate correlation with } \\
\text { prestige and large } \\
\text { correlation with influence. } \\
\text { Journal LP, prestige and } \\
\text { influence were unrelated. }\end{array}$ \\
\hline
\end{tabular}




\section{Appendix A (cont'd)}

\begin{tabular}{|c|c|c|c|c|c|c|}
\hline ID & $\begin{array}{l}\text { Author(s) } \\
\text { Year }\end{array}$ & Title & $\begin{array}{l}\text { Theoretical } \\
\text { Framework(s) }\end{array}$ & Methodology & $\begin{array}{l}\text { Context / } \\
\text { Participants }\end{array}$ & Key Findings \\
\hline S5 & $\begin{array}{l}\text { Shea et al. } \\
\text { (2014) }\end{array}$ & $\begin{array}{l}\text { Re- } \\
\text { conceptualizing } \\
\text { the community } \\
\text { of inquiry } \\
\text { framework: An } \\
\text { exploratory } \\
\text { analysis }\end{array}$ & $\begin{array}{l}\text { Community } \\
\text { of Inquiry } \\
\text { (LP, CP, TP, } \\
\text { SP) }\end{array}$ & $\begin{array}{l}\text { Content } \\
\text { analysis } \\
\text { SNA } \\
\text { Correlations } \\
\text { Wilicoxon- } \\
\text { Mann- } \\
\text { Whitney } \\
\text { Test }\end{array}$ & $\begin{array}{l}\text { Blended } \\
\text { learning } \\
\text { Doctoral } \\
\text { level course } \\
\text { Discussion } \\
\text { forum } \\
\mathrm{n}=18\end{array}$ & $\begin{array}{l}\text { TP did not play a } \\
\text { significant role in the } \\
\text { discussions. CP and SP } \\
\text { showed the highest level } \\
\text { of correlation followed } \\
\text { by CP and LP and SP } \\
\text { and LP. Students with } \\
\text { high CP, SP and LP had } \\
\text { high centrality. } \\
\text { Significant correlation } \\
\text { between centrality and } \\
\text { LP and centrality and } \\
\text { SP. }\end{array}$ \\
\hline S6 & $\begin{array}{l}\text { Tirado, } \\
\text { Hernando, } \\
\text { \& Aguaded } \\
(2015)\end{array}$ & $\begin{array}{l}\text { The effect of } \\
\text { centralization } \\
\text { and cohesion on } \\
\text { the social } \\
\text { construction of } \\
\text { knowledge in } \\
\text { discussion } \\
\text { forums }\end{array}$ & $\begin{array}{l}\text { Community of } \\
\text { inquiry } \\
\text { (SP, CP) }\end{array}$ & $\begin{array}{l}\text { Content } \\
\text { analysis } \\
\text { SNA } \\
\text { Structured } \\
\text { equation } \\
\text { modelling }\end{array}$ & $\begin{array}{l}\text { Blended } \\
\text { learning } \\
\text { Graduate } \\
\text { course } \\
\text { Discussion } \\
\text { forum } \\
\mathrm{n}=73\end{array}$ & $\begin{array}{l}\text { Network cohesion and } \\
\text { centralization correlate } \\
\text { positively and impact SP } \\
\text { and CP positively as well. }\end{array}$ \\
\hline S7 & $\begin{array}{l}\text { Wicks et al. } \\
(2015)\end{array}$ & $\begin{array}{l}\text { An evaluation of } \\
\text { low versus high } \\
\text { collaboration in } \\
\text { online learning }\end{array}$ & $\begin{array}{l}\text { Community of } \\
\text { inquiry } \\
\text { (LP) }\end{array}$ & $\begin{array}{l}\text { Content } \\
\text { analysis } \\
\text { SNA } \\
\text { Correlations } \\
\text { Wilicoxon- } \\
\text { Mann- } \\
\text { Whitney Test }\end{array}$ & $\begin{array}{l}\text { Online } \\
\text { learning } \\
\text { Graduate } \\
\text { course } \\
\text { Blogs, } \\
\text { Discussion } \\
\text { forum, CoI } \\
\text { survey } \\
\mathrm{n}=47\end{array}$ & $\begin{array}{l}\text { Student performance not } \\
\text { impacted by low or high } \\
\text { collaboration. Perceived TP } \\
\text { higher than SP in both } \\
\text { groups. Monitoring and } \\
\text { strategy most prominent LP } \\
\text { components. LP correlated } \\
\text { positively with prestige and } \\
\text { negatively with influence. }\end{array}$ \\
\hline S8 & $\begin{array}{l}\text { Jimoyiannis } \\
\text { \& Tsiotakis } \\
(2017)\end{array}$ & $\begin{array}{l}\text { Beyond students' } \\
\text { perceptions: } \\
\text { investigating } \\
\text { learning presence } \\
\text { in an educational } \\
\text { blogging } \\
\text { community }\end{array}$ & $\begin{array}{l}\text { Community of } \\
\text { inquiry } \\
\text { (CP, TP, SP) }\end{array}$ & $\begin{array}{l}\text { Content } \\
\text { analysis } \\
\text { SNA } \\
\text { Log-data } \\
\text { analysis } \\
\text { Blogging } \\
\text { maps }\end{array}$ & $\begin{array}{l}\text { Blended } \\
\text { learning } \\
\text { Undergraduate } \\
\text { course } \\
\text { Blogs } \\
\mathrm{n}=\text { not stated }\end{array}$ & $\begin{array}{l}\text { Decentralized learning } \\
\text { community which evolved } \\
\text { due to student initiatives } \\
\text { rather than efforts of the } \\
\text { tutor. }\end{array}$ \\
\hline
\end{tabular}




\section{Appendix A (cont'd)}

\begin{tabular}{|c|c|c|c|c|c|c|}
\hline ID & $\begin{array}{l}\text { Author(s) } \\
\text { Year }\end{array}$ & Title & $\begin{array}{l}\text { Theoretical } \\
\text { Framework }\end{array}$ & Methodology & $\begin{array}{l}\text { Context / } \\
\text { Participants }\end{array}$ & Key Findings \\
\hline S9 & $\begin{array}{l}\text { Jo, Park \& } \\
\text { Lee } \\
(2017)\end{array}$ & $\begin{array}{l}\text { Three } \\
\text { interaction } \\
\text { patterns on } \\
\text { asynchronous } \\
\text { online } \\
\text { discussion } \\
\text { behaviours: A } \\
\text { methodological } \\
\text { comparison }\end{array}$ & $\begin{array}{l}\text { Community } \\
\text { of inquiry } \\
\text { (CP) }\end{array}$ & $\begin{array}{l}\text { Content } \\
\text { analysis } \\
\text { SNA } \\
\text { Log-data } \\
\text { Analysis } \\
\text { Multiple } \\
\text { Regressions }\end{array}$ & $\begin{array}{l}\text { Blended } \\
\text { learning } \\
\text { University } \\
\text { level course } \\
\text { Discussion } \\
\text { forum } \\
\mathrm{n}=43\end{array}$ & $\begin{array}{l}\text { Visits on board and } \\
\text { student centralities } \\
\text { were predictive of } \\
\text { achievement. } \\
\text { Methodologies } \\
\text { combine well for } \\
\text { evaluation as each has } \\
\text { its strengths and } \\
\text { weaknesses. }\end{array}$ \\
\hline $\mathrm{S} 10$ & $\begin{array}{l}\text { Satar \& } \\
\text { Akcan } \\
(2018)\end{array}$ & $\begin{array}{l}\text { Pre-service } \\
\text { EFL teachers' } \\
\text { online } \\
\text { participation, } \\
\text { interaction, and } \\
\text { social presence }\end{array}$ & $\begin{array}{l}\text { Community } \\
\text { of Inquiry } \\
\text { (SP) }\end{array}$ & $\begin{array}{l}\text { Content } \\
\text { Analysis } \\
\text { SNA } \\
\text { Log-data } \\
\text { analysis } \\
\text { Wilcoxon } \\
\text { Signed Rank } \\
\text { Test } \\
\text { Spearman } \\
\text { Rho's } \\
\text { Correlation }\end{array}$ & $\begin{array}{l}\text { Online } \\
\text { learning } \\
\text { Undergraduate } \\
\text { course } \\
\text { Discussion } \\
\text { forum } \\
\mathrm{n}=37 \text { and } 20\end{array}$ & $\begin{array}{l}\text { Significant } \\
\text { relationships between } \\
\text { all SNA measures and } \\
\text { interactive indicators } \\
\text { of SP in the fall } \\
\text { semester but not in the } \\
\text { spring semester. } \\
\text { Findings were } \\
\text { inconclusive. }\end{array}$ \\
\hline
\end{tabular}




\section{Appendix B}

\begin{tabular}{|c|c|c|c|}
\hline No. & SNA Measures & $\begin{array}{c}\text { CoP \& CoI } \\
\text { Theoretical Components } \\
\end{array}$ & Complementary Techniques \\
\hline S1 & $\begin{array}{l}\text { Density } \\
\text { In-degree Centrality } \\
\text { Out-degree Centrality }\end{array}$ & $\begin{array}{l}\text { Indicator of SP. } \\
\text { Indicator of influence linked to CP, TP, SP. } \\
\text { Indicator of prestige linked to CP, TP, SP. }\end{array}$ & Content Analysis (CP, TP, SP) \\
\hline $\mathrm{S} 2$ & $\begin{array}{l}\text { Density and Cohesion } \\
\text { Cliques }\end{array}$ & $\begin{array}{l}\text { Participation trajectory of whole } \\
\text { community. } \\
\text { Number of cliques indicator of community } \\
\text { development. Structure of cliques impact } \\
\text { individual trajectories. Interaction within } \\
\text { and across cliques representative of } \\
\text { overlapping CoP. Linked to local versus } \\
\text { global interactions and sense of belonging } \\
\text { within and across groups. } \\
\text { Indicator of individual trajectories and } \\
\text { social power. Negotiation of status and roles } \\
\text { within community. }\end{array}$ & $\begin{array}{l}\text { Content Analysis (to identify } \\
\text { addressee) } \\
\text { General Analysis of Discussions } \\
\text { (excerpt provided) }\end{array}$ \\
\hline S3 & $\begin{array}{l}\text { Cohesion } \\
\text { Cliques }\end{array}$ & $\begin{array}{l}\text { Sharing ideas and beliefs linked to creation } \\
\text { of knowledge } \\
\text { Community architecture. Clique members } \\
\text { as drivers of knowledge creation process. } \\
\text { Number of cliques indicates degree of } \\
\text { interaction and determines scope of } \\
\text { communication } \\
\text { Power linked to spreading information and } \\
\text { influencing others. Identification of lurkers }\end{array}$ & $\begin{array}{l}\text { Content Analysis (CP, TP, SP) } \\
\text { Log Data Analysis for each group } \\
\text { to identify prominent groups for } \\
\text { SNA and CA }\end{array}$ \\
\hline S4 & $\begin{array}{l}\text { In-degree Centrality } \\
\text { Out-degree Centrality }\end{array}$ & $\begin{array}{l}\text { Indicator of influence linked to LP. } \\
\text { Indicator of prestige linked to LP. }\end{array}$ & Content Analysis (LP) \\
\hline S5 & $\begin{array}{l}\text { In-degree Centrality } \\
\text { Out-degree Centrality }\end{array}$ & $\begin{array}{l}\text { Indicator of influence linked to LP, CP, SP, } \\
\text { TP. } \\
\text { Indicator of prestige linked to LP, CP, SP, } \\
\text { TP. }\end{array}$ & $\begin{array}{l}\text { Content Analysis (CP, TP SP, LP) } \\
\text { Wilcoxon-Mann-Whitney Test } \\
\text { Spearman Rho's Correlation }\end{array}$ \\
\hline S6 & $\begin{array}{l}\text { Density and Cohesion } \\
\text { Centralization }\end{array}$ & $\begin{array}{l}\text { Indicator of rate of participation. } \\
\text { Global cohesion as an indicator of degree } \\
\text { centralization. } \\
\text { Measurement of collective communication. }\end{array}$ & $\begin{array}{l}\text { Content Analysis (SP, CP) } \\
\text { Structured Equation Modelling } \\
\text { (SEM) }\end{array}$ \\
\hline S7 & $\begin{array}{l}\text { In-degree Centrality } \\
\text { Out-degree Centrality }\end{array}$ & $\begin{array}{l}\text { Indicator of influence linked to LP. } \\
\text { Indicator of prestige linked to LP. }\end{array}$ & $\begin{array}{l}\text { Content Analysis (LP) } \\
\text { CoI survey } \\
\text { Pre-test and post-test } \\
\text { Correlational Analysis } \\
\text { Wilcoxon-Mann-Whitney Test }\end{array}$ \\
\hline
\end{tabular}


S8 Cohesion

Cliques

\section{Degree Centrality}

Hierarchical

Clustering

S9

Density
Degree Centrality
In-Degree Centrality
Out-Degree Centrality

Sharing ideas and beliefs linked to creation of knowledge

Community architecture. Clique members as drivers of knowledge creation process. Number of cliques indicates degree of interaction and determines scope of communication. Conducted on whole network.

Power linked to spreading information and influencing others. Identification of lurkers. Identification of similar nodes.

Indicator of participation rate over time.

Assessment of whole network centralization.

Used for regression analysis.

Indicators of SP

Density

Centralization

Components

Connectedness

Fragmentation

Average distance

Diameter

Compactness

In-Degree Centrality

Out-Degree Centrality
Content Analysis (CP, TP, SP)

Blogging Maps

Log Data Analysis
Content Analysis (CP)

Log Data Analysis

Multiple Regression Analysis

Content Analysis (SP)

Log Data Analysis

Wilcoxon Signed Rank Test

Spearman Rho's Correlation

Appendix B. SNA Measures, CoP \& CoI Theoretical Components, and Complimentary Techniques 